\title{
Prezentacja polonistyki na Uniwersytecie Mateja Bela w Bańskiej Bystrzycy
}

Pierwsza rekrutacja studentów polonistyki na Uniwersytecie Mateja Bela w Bańskiej Bystrzycy odbyła się w 1997 roku. Do 2007 roku polonistyka wraz z innymi językami słowiańskimi tworzyła Katedrę Języków Słowiańskich na Wydziale Filologicznym, a następnie po fuzji wydziałów funkcjonuje w ramach Wydziału Filozoficznego. Katedrę tworzyły: rusycystyka, ukrainistyka, białorusycystyka, serbistyka, kroatystyka i bułgarystyka. Niestety obecnie Katedra składa się już tylko z rusycystyki i polonistyki.

Istnienie polonistyki, prowadzenie działalności pedagogicznej i naukowej nie byłoby możliwe bez doświadczonej kadry nauczycielskiej. Dogodne położenie Bańskiej Bystrzycy, tzn. bliskość polskiej granicy, a w związku z tym polskich uczelni, sprawia, że przy braku na Słowacji profesorów gwarantów kadrę wykładowców wzmacniają pracownicy południowych polskich uczelni. Pozycję koordynatorów programu „Język polski i kultura” zajmowali polscy profesorowie: prof. Józef Kąś z Uniwersytetu Jagiellońskiego, prof. Urszula Żydek-Bednarczuk z Uniwersytetu Śląskiego i od 2012 roku prof. Władysław Śliwiński z Uniwersytetu Jagiellońskiego, przyczyniając się w znacznej mierze do rozwoju bańskobystrzyckiej polonistyki. Dzielili się swoimi doświadczeniami naukowo-dydaktycznymi, a przede wszystkim wiedzą. Ponadto nawiązywali kontakty z zagranicznymi placówkami polonistycznymi i organizowali seminaria.

Aktualnie wykładowcami na polonistyce są: prof. dr hab. Władysław Śliwiński, dr hab. Gabriela Olchowa, dr Anita Račáková i lektor mgr Jakub Pacześniak.

Prof. Władysław Śliwiński prowadzi wykłady i seminaria z leksykologii, stylistyki, frazeologii, retoryki, tekstologii i kultury języka polskiego. 
Jest członkiem Komisji Językoznawstwa Oddziału Polskiej Akademii Nauk w Krakowie i członkiem zarządu Komisji Socjolingwistycznej przy Międzynarodowym Komitecie Slawistów. Zajmuje się przede wszystkim kulturą współczesnego języka polskiego, językiem polskiej telewizji, konstrukcjami nominalnymi w języku artystycznym. Jest autorem lub współautorem sześciu monografii, m.in. Łączliwość składniowo-semantyczna przymiotników z rzeczownikami we wspótczesnym języku polskim; Produktywność syntaktyczna leksemów w poetyckich konstrukcjach nominalnych od XVI do XXI wieku; Poetyckie konstrukcje nominalne $w$ dziejach polskiego wiersza oraz Stownika semantyczno-syntaktycznego przymiotników polskich. Badacz realizuje grant na temat Stownictwo dyferencjalne w dramatach Stanisława Wyspiańskiego - studia leksykologiczno-leksykograficzne, którego rezultatem będzie pięć monografii wydanych przez zespół, poświęconych archaizmom leksykalnym, kategorii potoczności, neologizmom językowym, terminologii i słownictwu specjalistycznemu oraz dialektyzmom i kulturze ludowej w dramatach Wyspiańskiego. Ponadto pod redakcją prof. Władysława Śliwińskiego przygotowywany jest Słownik osobliwości leksykalnych S. Wyspiańskiego. Należy także wspomnieć o serii wydawniczej „Z dziejów polszczyzny artystycznej”, którą uruchomił Pan Profesor w krakowskim wydawnictwie Libron.

Dr hab. Gabriela Olchowa w latach 2002-2007 pracowała w Katedrze Języków Słowiańskich jako lektorka, a następnie objęła stanowisko starszego asystenta. Wykłada i prowadzi ćwiczenia z gramatyki opisowej współczesnego języka polskiego, leksykografii, historii i geografii Polski, polskich mitów i symboli oraz wstępu do socjokultury. Jest redaktorem serii ,Język Polski i Kultura" i autorką monografii Przejawy perswazji w strukturze siedemnastowiecznych kazań polskiego kaznodziei Szymona Starowolskiego, redaktorem tomu pokonferencyjnego Výučba slovanských jazykov ako cudzích $v$ slovanskom prostredi - súčasnost'a perspektivy i współautorką wraz z Władysławem Śliwińskim i Anitą Račákovą tomu Stowiański dialog kulturowy. Studia leksykalne i gramatyczne. Prowadzi badania w ujęciu porównawczym z zakresu etykiety językowej i języka religii. Zajmuje się także glottodydaktyką, a zwłaszcza nauczaniem kompetencji socjokulturowej. Interesuje się również stosunkami polsko-słowackimi oraz krytyką przekładu. Brała udział w projektach: Slovanský romantizmus v európskych a svetových súvislostiach; Slovanské literatúry 20. storočia - dialóg kultúr, jazykov a areálu; Nauczaniejęzyków stowiańskich jako obcych w środowisku stowiańskim - stan obecny a perspektywy. Ponadto wspólnie z Anitą Račákovą i Jakubem Pacześniakiem była lektorką specjalistycznego kursu języka polskiego dla operatorów numeru alarmowego 112, dyspozytorów, policjantów, ratowników górskich w ramach projektu słowac- 
kiego Ministerstwa Spraw Wewnętrznych Národný program vzdelávania IZS vo väzbe na podporu človeka v tiesni a úlohy v oblasti bezpečnosti štátu.

Dr Anita Račáková prowadzi wykłady ze wstępu do tłumaczenia specjalistycznego, ćwiczenia i seminaria z thumaczenia pisemnego, thumaczenia ustnego konsekutywnego i symultanicznego oraz thumaczenia dla instytucji Unii Europejskiej. Zainteresowania badawcze kieruje w stronę komunikacji międzykulturowej, nauczania kompetencji międzykulturowej przyszłych tłumaczy, kolokacji w tekstach prawnych i ekonomicznych z aspektu porównawczego słowacko-polskiego. Brała udział w następujących projektach: Slovensko-pol'ské pomedzie. Jazyk, l'udová kultúra a dejiny osídlenia; Slovanské literatúry 20. storočia - dialóg kultúr, jazykov a areálu; Reciprocita a tenzia translácie a interkultúrnej komunikácie. Oprócz tego nowe podane projekty to: Pol'sko-slovenská lingvistická terminológia; Hybridita v jazyku, texte, translácii; Dwujęzyczny podręcznik do nauczania języka dla służb ratowniczych z pogranicza polsko-stowackiego.

Mgr Jakub Pacześniak jest szóstym z kolei lektorem języka polskiego na bańskobystrzyckiej uczelni. Jak dotąd wszyscy lektorzy pochodzili z południowych ośrodków: Uniwersytetu Śląskiego, Uniwersytetu Opolskiego i Uniwersytetu Jagiellońskiego. Lektor prowadzi nie tylko praktyczne ćwiczenia językowe, ale również seminaria z literatury i kultury polskiej. Do zakresu jego działalności należy: organizacja różnego rodzaju imprez, np. spotkań z polskimi pisarzami i artystami, wycieczek, współpraca z polskimi fundacjami, Instytutem Pamięci Narodowej, Instytutem Książki.

Pracownicy polonistyki organizowali konferencje, seminaria oraz warsztaty thumaczeniowe. Na Uniwersytecie Mateja Bela odbyły się zatem międzynarodowe konferencje naukowe: z okazji 10-lecia polonistyki Nauczanie języków stowiańskich jako obcych w środowisku stowiańskim - stan obecny i perspektywy (2008), następnie Dialog kulturowy języków stowiańskich (2012), dalej w 2013 roku we współpracy ze Stowarzyszeniem „Bristol” Polskich i Zagranicznych Nauczycieli Kultury Polskiej i Języka Polskiego jako Obcego konferencja na temat Język w kulturze, kultura w języku. Ostatnio zorganizowaną konferencją było spotkanie na temat Języki stowiańskie w procesie przemian (2015), na którą przybyli naukowcy z Instytutu Filologii Polskiej i Instytutu Filologii Słowiańskiej Uniwersytetu im. Adama Mickiewicza w Poznaniu, Uniwersytetu Wrocławskiego, Uniwersytetu Ostrawskiego i Uniwersytetu Preszowskiego. Z kolei z okazji Dnia Niepodległości Polski miały miejsce polsko-słowackie seminaria naukowe pt. Kultura, literatura i język w nauczaniu języka polskiego jako obcego, które odbyły się już trzykrotnie w 2008, 2010 i 2012 roku. Ponadto w 2009 roku gościliśmy studentów kulturoznawstwa Uni- 
wersytetu Śląskiego, przybyłych na seminarium dla studentów i doktorantów, które poświęcone było językoznawczym i kulturowym aspektom reklamy.

Do dalszej działalności naukowej bańskobystrzyckiej polonistyki zaliczyć można wydawanie serii tomów „Język Polski i Kultura”. Publikacja jest głosem polonistów - zarówno wykładających w kraju, jak i za granicą. Jej celem jest promocja języka i kultury polskiej na Słowacji, prowadzenie dyskusji naukowej umożliwiającej współpracę i wymianę polskich i słowackich doświadczeń. Do tej pory ukazały się dwa tomy pod redakcją Gabrieli Olchowej - Język, literatura i kultura w dydaktyce języka polskiego jako obcego (2010) i Między dawnymi a nowymi czasy. Język - Literatura - Kultura - Media (2012).

Z inicjatywy pracowników bańskobystrzyckiej polonistyki powstało Centrum Kultury i Języka Polskiego, które uroczyście otwarto w 2012 roku. Jednostka ma swoją siedzibę i działa na Uniwersytecie Mateja Bela, ale blisko współpracuje z Polskim Instytutem w Bratysławie. Stanowi forum, na którym dochodzi do nawiązania kontaktów, spotkań, współpracy i wymiany doświadczeń między polską i słowacką społecznością. Do głównych zadań Centrum należy:

a) współpraca ze słowackimi i polskimi ośrodkami naukowymi i kulturalnymi, Państwową Biblioteką Naukową (Štátnou vedeckou knižnicou) w Bańskiej Bystrzycy, gdzie znajduje się Slovanska študovňa - Studium Słowiańskie; współpraca z Akademią Sztuk Pięknych (m.in. poprzez tłumaczenie dramatów polskich wystawianych na scenach tej uczelni);

b) organizacja spotkań z osobistościami świata nauki, kultury, polityki;

c) realizacja naukowych badań dotyczących dialogu międzykulturowego;

d) promowanie studiów polonistycznych;

e) szerzenie wiedzy z języka i kultury polskiej;

f) organizacja warsztatów tłumaczeniowych;

g) w perspektywie - prowadzenie kursów języka polskiego dla szerokiej społeczności słowackiej.

Należy tu wspomnieć także o współpracy polonistyki z uczelniami zagranicznymi. Rozwijamy kontakty z polskimi uczelniami oraz z innymi ośrodkami polonistycznymi w Europie Środkowej. Wydział Filozoficzny i Uniwersytet Mateja Bela mają podpisane dwustronne umowy z 27 uniwersytetami w Polsce. Najściślej jednak współpracujemy z Uniwersytetem Rzeszowskim, Uniwersytetem Śląskim, Uniwersytetem Jagiellońskim i Uniwersytetem Zielonogórskim. Pracownicy i studenci wyjeżdżają na staże do Katowic, Krakowa, Warszawy, Olsztyna, Lublina, Rzeszowa albo do Czech na ostrawską polonistykę. Z kolei my gościliśmy wykładowców z Uniwersytetu Śląskiego, 
Uniwersytetu Rzeszowskiego, Uniwersytetu Marii Curie-Skłodowskiej, Katolickiego Uniwersytetu Lubelskiego, Uniwersytetu Zielonogórskiego, z Akademii Techniczno-Humanistycznej w Bielsku-Białej, Uniwersytetu Łódzkiego czy Uniwersytetu Radomskiego.

Polonistyka to przede wszystkim studenci. Nabór na studia odbywa się każdego roku, a studenci przyjmowani są bez egzaminów wstępnych, zaś naukę języka polskiego rozpoczynają od zera. Obecnie w formie stacjonarnej mogą studiować tylko język polski lub język polski w kombinacji z językiem angielskim, francuskim, niemieckim, hiszpańskim, włoskim. Natomiast z drugich języków muszą zdać egzaminy wstępne. Trzeba zaznaczyć, że oba języki są na naszej uczelni równorzędne, a studenci mają tę samą liczbę godzin z danego języka zarówno na polonistyce, jak i na pozostałych filologiach. Na Słowacji jedynie na UMB można studiować zaocznie polonistykę na studiach licencjackich i magisterskich. Należy podkreślić, że wszystkie wykłady i ćwiczenia prowadzone są wyłącznie w języku polskim. Program nauczania składa się z bloku przedmiotów językoznawczych, kulturowych, a zwłaszcza z bloku przedmiotów ściśle związanych z thumaczeniem, dzięki którym studenci otrzymują solidną teoretyczną i praktyczną wiedzę o przekładzie, opanowują metodologie thumaczenia, thumaczą teksty specjalistyczne i dokumenty, poznają budowę tekstów specjalistycznych, pism instytucji Unii Europejskiej oraz terminologię z dziedziny polityki, ekonomii, techniki, prawa, medycyny, ruchu turystycznego itp. Tłumaczenia konferencyjne, konsekutywne i symultaniczne wymagają zupełnie innej dydaktyki i metodologii, a przede wszystkim odpowiedniego laboratorium. Poloniści mają dostęp do czterech takich sal wykładowych i trzeba tu podkreślić, że jako jedyni spośród polonistów na Słowacji. Wspomniane pracownie wyposażone są w kabiny, w których są dyktafony cyfrowe i odtwarzacze MP3, telewizor LCD oraz pulpit sterujący dla nauczyciela, a także laboratorium do tłumaczenia kabinowego. Oprócz tego nasi studenci co roku wyjeżdżają na darmowe pobyty w letnich szkołach w Polsce, mają możliwość wyjazdu na wycieczki (zwiedzili już Opole, Wrocław, Kraków, Warszawę, Częstochowę, Zakopane), biorą udział w spotkaniach z wybitnymi osobistościami literatury i kultury polskiej: Andrzejem Stasiukiem, Wojciechem Kuczokiem, Krzysztofem Lisowskim, Marcinem Baranem, Zbigniewem Zadurą, Dariuszem Foksem. Ponadto organizowane są wieczory w Filmowym Klubie Polonistów, wystawy dotyczące historii Polski w XX wieku (Instytut Pamięci Narodowej), warsztaty tłumaczeniowe, np. z Józefem Marušiakem, Karolem Chmelem, albo warsztaty z zakresu komunikacji werbalnej i niewerbalnej prowadzone przez psychologów z Rzeszowa, a także andrzejki, wigilie, bale itp. 
Trudno byłoby zorganizować większość tych imprez bez pomocy i wsparcia Instytutu Polskiego w Bratysławie oraz Ambasady RP wraz z Wydziałem Konsularnym. Przedstawiciele tych instytucji wspomagają nas, spotykają się ze studentami, pracownikami i władzami uczelni. Jednak nie tylko służą radą - przyczynili się także do organizacji wielu spotkań, biesiad literackich, konferencji czy wykładów.

18 lat polonistyki to niedługi czas, ale pragnę w tym miejscu przytoczyć wypowiedź byłego dyrektora Instytutu Polskiego w Bratysławie - Zbigniewa Macheja:

Konsekwentne działania władz Uniwersytetu Mateja Bela, kompetencje, poświęcenie i determinacja młodej, polonistycznej kadry naukowej, owocna współpraca z różnymi środowiskami polonistycznymi w Polsce - wszystko to przyniosło wkrótce znaczące dokonania dydaktyczne i naukowe. Dorobek bańskobystrzyckiej polonistyki osiągnięty w tak krótkim czasie zasługuje na wielkie uznanie. [...] Bańskobystrzycka polonistyka może być uznana za najważniejszy ośrodek polonistyczny na Słowacji. [Račáková, red. 2008: 5]

Gabriela Olchowa

\section{Bibliografia}

Račáková Anita, red. (2008), 10 rokov polonistiky na Univerzite Mateja Bela v Banskej Bystrici, Univerzita Mateja Bela v Banskej Bystrici Fakulta humanitných vied., Banská Bystrica. 